\title{
"Proíbo a publicação \\ e circulação..." - censura \\ a livros na ditadura militar
}

\author{
SANDRA REIMÃO ${ }^{I}$
}

$\mathrm{U}$ MA DAS PRIMEIRAS providências dos regimes autoritários é restringir a liberdade de expressão e opinião; trata-se de uma forma de dominação pela coerção, limitação ou eliminação das vozes discordantes.

No Brasil, durante a ditadura militar (1964-1985), e destacadamente a partir da Constituição outorgada de 1967, a censura oficial do Estado em relação a filmes, peças teatrais, discos, apresentações de grupos musicais, cartazes e espetáculos públicos em geral era exercida pelo Ministério da Justiça (MJ) por meio do Serviço de Censura de Diversões Públicas (SCDP), setor do Departamento de Censura de Diversões Públicas (DCDP). A partir de 1970, livros e revistas também passaram a ser examinados pelo SCDP-DCDP.

Este artigo aborda a censura oficial a livros, destacadamente obras de autores brasileiros, durante a ditadura militar brasileira - com ênfase no período posterior a 1970, data do Decreto-Lei n.1077/70 que regulamentou a censura a livros e revistas.

Com estudo dos atos censórios do DCDP em relação aos livros é possível delinear alguns mecanismos da censura e refletir sobre a repercussão da censura no universo da produção cultural brasileira.

\section{Cultura, censura e livros - breve observação inicial}

Entre os anos 1964 e 1968, isto é, entre o golpe militar de 1964 e a decretação do AI-5, a censura a livros no Brasil foi marcada por uma atuação confusa e multifacetada, pela ausência de critérios mesclando batidas policiais, apreensões, confiscos e coerção física. "As ações confiscatórias ocorriam de forma primária, improvisada, efetuadas por pessoas mal treinadas" (Stephanou, 2001, p.215).

O alvo predileto da atuação aleatória das forças de repressão, entre 1964 e 1968, no que tange à apreensão, coação e censura de livros, foi o editor Énio Silveira, proprietário da Editora Civilização Brasileira. Ênio Silveira foi preso e processado várias vezes, outras tantas viu a editora ser invadida e sua produção editorial, apreendida.

Em maio de 1965, a prisão de Ênio Silveira provocou um manifesto assinado por cerca de mil pessoas ligadas ao universo da cultura. O presidente Castelo Branco mandou para Ernesto Geisel, à época chefe de Gabinete Militar, 
a seguinte correspondência: "Por que a prisão do Ênio? Só para depor? A repercussão é contrária a nós [...]. Apreensão de livros. Nunca se fez isso no Brasil. Só de alguns (alguns!) livros imorais. Os resultados são os piores possíveis contra nós. É mesmo um terror cultural" (Gaspari, 2002a, p.96-7).

Em um corajoso e claro ato de resistência ao governo militar, em maio de 1966, a editora Civilização Brasileira impetrou Mandado de Segurança contra o Departamento Federal de Segurança Pública questionando as várias ações confiscatórias de livros. Na revista Civilização Brasileira (n.9/10, p.291-7) encontra-se a reprodução integral desse Mandado.

Em 1968, o terrorismo de direita provocou, segundo os cálculos de Elio Gaspari, dezessete atentados, quatorze explosões e um assalto a banco. Editoras e livrarias estavam entre os alvos: foram atingidas a editora Tempo Brasileiro, a Civilização Brasileira e a Livraria Forense (Gaspari, 2002a, p.328 e 301).

Embora espaços do universo dos livros, editoras, livrarias, fossem alvos de vandalismo de direita, não houve nos primeiros anos após o golpe militar de 1964 a estruturação de um sistema único de censura a livros. Essa ausência de uma regulamentação censória em relação a livros possibilita que entre os best-sellers de 1968 constem, por exemplo, clássicos do pensamento nacional de esquerda, como Um projeto para o Brasil, de Celso Furtado, e clássicos internacionais da literatura erótica, como Kama Sutra, literatura hindu de fisiologia e moral sexual, e Filosofia na alcova, do Marquês de Sade (Reimão, 1996, p.43-50).

A Constituição outorgada de 1967 oficializou a centralização da censura como atividade do governo federal, em Brasília. Quando o Ato Institucional número 5 foi decretado, as atividades censórias já se encontravam centralizadas no governo federal.

Duas grandes manifestações públicas contra as arbitrariedades do regime militar ocorridas no Rio de Janeiro antecederam a decretação do AI-5: a manifestação “Cultura contra Censura”, em fevereiro de 1968, que reuniu membros da classe teatral para manifestarem sua indignação contra a proibição da encenação de oito peças (Castro, 2000, p.370) e, alguns meses mais tarde, aquela que ficou conhecida como "A Passeata dos Cem Mil”, em 26 de junho de 1968 (Ventura, 1988, p.155-65).

Sexta-feira, 13 de dezembro de 1968. Em nome da "autêntica ordem democrática $[. .$.$] (e) no combate à subversão e às ideologias contrárias às tradições$ de nosso povo", o presidente Costa e Silva editou o Ato Institucional número 5 (AI-5). A edição desse ato tornou possível cassar mandatos, suspender direitos políticos e garantias individuais e criou condições para a censura à divulgação da informação, à manifestação de opiniões e às produções culturais e artísticas. Começa aí o período chamado "anos de chumbo".

Na segunda metade da década de 1970, escritores, editores, intelectuais, artistas, cientistas, professores começaram a mobilizar-se para resistir e protestar contra os desmandos e arbítrios de um regime autoritário. Essa resistência 
da sociedade aos atos autoritários do governo de então culminou com várias demonstrações e atos públicos de repúdio ao autoritarismo. No que diz respeito às manifestações pelas liberdades no âmbito das produções culturais destaca-se o Manifesto dos 1046 intelectuais contra a censura, entregue ao ministro da Justiça em Brasília, em 25 de janeiro de 1977, por uma comissão composta por Helio Silva, Lygia Fagundes Telles, Nélida Pinõn e Jefferson Ribeiro de Andrade.

Em 13 de outubro de 1978 foi promulgada pelo Congresso Nacional a Emenda Constitucional número 11 que revogava, a partir de $1^{\circ}$ de janeiro de 1979, o AI-5.

Nos dez anos de vigência do AI-5 (13 de dezembro de 1968 a 31 de dezembro de 1978), segundo estimativas apresentadas por Zuenir Ventura, 1.607 cidadãos foram atingidos direta e explicitamente por esse Ato com punições como cassação, suspensão de direitos políticos, prisão e/ou afastamento do serviço público. No que tange ao cerceamento da produção artística e cultural, nos dez anos de vigência do AI-5 foram censurados, ainda segundo dados apresentados por Zuenir Ventura (1988, p.285), "cerca de 500 filmes, 450 peças de teatro, 200 livros, dezenas de programas de rádio, 100 revistas, mais de 500 letras de música e uma dúzia de capítulos e sinopses de telenovelas".

\section{Livros de autores brasileiros e censura}

A censura prévia, já anteriormente regulamentada para cinema, televisão, teatro, espetáculos públicos, música e rádio, e prática presente em várias revistas e jornais impressos se expandiu, e para a totalidade do mercado editorial depois da centralização do Serviço de Censura de Diversões Públicas (SCDP), em Brasília.

A censura prévia para livros foi regulamentada pelo Decreto-Lei n.1.077 $/ 70$. Os art. $1^{\circ}$ e $2^{\circ}$ desse decreto estavam assim redigidos:

Art. $1^{\circ}$ Não serão toleradas as publicações e exteriorizações contrárias à moral e aos bons costumes quaisquer que sejam os meios de comunicação; Art. $2^{\circ}$ Caberá ao Ministério da Justiça, através do Departamento de Polícia Federal verificar, quando julgar necessário, antes da divulgação de livros e periódicos, a existência de matéria infringente da proibição enunciada no artigo anterior.

Depois de anunciar o que deveria ser censurado, o mesmo decreto versa sobre as sanções:

Art. $3^{\circ}$ Verificada a existência de matéria ofensiva à moral e aos bons costumes, o Ministro da Justiça proibirá a divulgação da publicação e determinará a busca e a apreensão de todos os seus exemplares. [...] Art. $5^{\circ} \mathrm{A}$ distribuição, venda ou exposição de livros e periódicos que não hajam sido liberados ou que tenham sido proibidos, após a verificação prevista neste Decreto-lei, sujeita os infratores, independentemente da responsabilidade criminal. 
A Portaria 11-B, de 6 de fevereiro de 1970, para operacionalizar o Decreto n.1.077/70, determinava que todas as publicações deveriam ser previamente encaminhadas para o Ministério da Justiça para julgamento. A reação adversa de editores, escritores, intelectuais e associações da sociedade civil foi grande, relata, entre outros, Antonio Costela (1970) no livro O controle da imprensa no Brasil, publicado no calor da hora, em 1970.

Liderando a oposição à censura prévia para livros destacaram-se Jorge Amado e Erico Verissimo, líderes também de vendagens na época, que declararam publicamente "em nenhuma circunstância mandaremos os originais de nossos livros aos censores, nós preferimos parar de publicar no Brasil e só publicar no exterior" (Jones, 2001, v.1, p.46).

A incisiva reação contra o estabelecimento da censura prévia para livros e publicações em geral levou o governo a recuar e a publicar uma nova Instrução para a Portaria 11-B, a Instrução número 1-70 de 24 de fevereiro de 1970 que explicita que "estão isentas de verificação prévia as publicações e exteriorizações de caráter estritamente filosófico, científico, técnico e didático, bem como as que não versarem sobre temas referentes ao sexo, moralidade pública e bons costumes".

Foi um avanço democrático conseguido pelas forças sociais do momento, mas é claro também que os limites para decidir se um texto enfoca ou não, tangencia ou não, temas de moralidade pública, bons costumes ou sexo, são limites bastante móveis e essa mobilidade permitiu que relevantes obras - teóricas, conceituais e ficcionais - fossem alvo de rigorosos atos censórios.

A maioria da atividade de censura em relação a livros dava-se, na prática, por denúncias. Segundo descrição publicada na revista Veja de 29.12.1976 (p.81-2), a censura a livros dava-se da seguinte forma:

Alguém que tenha lido um livro [...] e o considere atentatório à moral ou mesmo subversivo, faz uma denúncia ao Ministério. Instala-se, então, um processo no qual é dada a um assessor do ministro da Justiça a tarefa de ler a publicação e emitir parecer. Com base neste, o ministro decreta ou não a apreensão.

Mesmo assim, continua a descrição da revista Veja, "as superintendências regionais da Polícia Federal costumam receber livros para censura prévia, de editoras que temem uma apreensão posterior à publicação".

A censura prévia para todos os livros seria inexequível. Uma matéria da revista Visão de 11.3.1974 salienta essa impossibilidade técnica: "só em 1971 foram lançados no Brasil 9.950 títulos novos, que exigiriam um número incalculável de censores".

Na primeira metade da década de 1970, no chamado "Milagre Brasileiro", a edição de livros cresceu em número de títulos editados e também em número de exemplares. Em 1972, o Brasil ultrapassou a barreira de um livro por habitante ao ano. Em 1972 a população brasileira era de 98 milhões de habitantes 
e foram produzidos 136 milhões de livros - 1,3 livro por habitante (Reimão, 1996, p.59-65).

Os dados gerais sobre a ação da censura a livros nesse período são conflitantes: Zuenir Ventura, em 1968 o ano que não terminou, indica que entre 1968 e 1978 foram censurados 200 livros; um levantamento realizado pela equipe de pesquisadores do Centro Cultural São Paulo e publicada no livro Cronologia das Artes em São Paulo - 1975-1995, indica esses mesmos números (CCSP, 1996, v.1, p.41). Deonísio da Silva (1989), no livro Nos bastidores da censura, indica 430 livros proibidos pela censura federal durante o regime militar, sendo cerca de 92 obras de autores brasileiros.

Em Brasília, no subsolo do prédio do Arquivo Nacional, encontram-se os documentos que restaram da Divisão de Censura de Diversões Públicas. Em 1988, com a promulgação da nova Constituição, que bania a censura, o DCDP foi desativado e sua documentação foi transferida para o Arquivo Nacional; é possível que nesse momento muitos documentos tenham sido eliminados, extraviados ou perdidos. Mesmo assim, trata-se de um acervo grande e de enorme valor histórico.

No que tange ao material dos processos de censura prévia em relação a publicações (livros e revistas), o universo dos documentos é bastante pequeno se comparado com o material referente a obras cinematográficas e teatrais. Segundo levantamento realizado por funcionários do Arquivo, há registros de cerca de 490 livros e 97 revistas que foram submetidas ao DCDP:

Quadro l - Fundo - DCDP / Seção - Censura Prévia / Série Publicações

\begin{tabular}{c|c|c|c|c}
\hline Ano & $\begin{array}{c}\text { Livros } \\
\text { submetidos }\end{array}$ & Livros vetados & $\begin{array}{c}\text { Revistas } \\
\text { submetidas }\end{array}$ & Revistas vetadas \\
\hline 1970 & 25 & $5-20 \%$ & 1 & $1-{ }^{*}$ \\
\hline 1971 & 6 & $0--$ & 0 & $0-{ }^{*}$ \\
\hline 1972 & 16 & $2-12,5 \%$ & 5 & $3-{ }^{*}$ \\
\hline 1973 & 11 & $4-36,3 \%$ & 1 & $0-{ }^{*}$ \\
\hline 1974 & 20 & $11-55 \%$ & 2 & $3-20 \%$ \\
\hline 1975 & 132 & $109-82 \%$ & 15 & $3-7 \%$ \\
\hline 1976 & 100 & $61-61 \%$ & 42 & $4-36 \%$ \\
\hline 1977 & 49 & $30-61 \%$ & 11 & $2-25 \%$ \\
\hline 1978 & 84 & $62-73 \%$ & 8 & $1-{ }^{*}$ \\
\hline 1979 & 47 & $38-80 \%$ & 2 & $1-{ }^{*}$ \\
\hline 1980 & 0 & $0-$ & 4 & $3-{ }^{*}$ \\
\hline 1981 & 1 & $1-{ }^{*}$ & 2 & $0-{ }^{*}$ \\
\hline 1982 & 1 & $0--$ & 3 & 1 \\
\hline 1988 & 0 & $0--$ & & \\
\hline
\end{tabular}

* não calculamos o percentual em razão do reduzido tamanho do universo. 
Em qualquer afirmação sobre esses dados, não podemos esquecer que se trata da documentação preservada e que não sabemos a que percentual do total originalmente existente essa documentação corresponde. Dentro desse universo, de qualquer modo, eliminando os livros dos quais não constam autoria e os que figuram como de autores cujos nomes não conseguimos identificar a nacionalidade (dezesseis), da listagem total de aproximadamente 490 livros submetidos ao DCDP, cerca de 140 são de autores nacionais; desses, 70 foram vetados, e 60 deles podem ser classificados como eróticos/pornográficos. (Os números são sempre aproximados, pois há livros que foram apresentados mais de uma vez e há livros que foram apresentados com nomes diferentes.)

\section{Teatro em livros}

Em 1970, o Serviço Nacional de Teatro encaminhou ao DCDP vinte textos de peças teatrais de dramaturgos brasileiros que seriam publicados em formato de livro. Desses, quatro foram vetados pelo DCDP: Pavana para um macaco defunto, de Antônio Galvão Naclério Novaes; Papa Highirte, de Oduvaldo Vianna; O sótão e o rés do chão ou Soninha toda pura, de José Ildemar Ferreira; e A farsa do bode expiatório, de Luiz Maranhão Filho (a documentação desses processos encontra-se no Arquivo Nacional).

De acordo com o levantamento realizado por Deonísio da Silva (1989), sete outros textos teatrais de autores nacionais tiveram sua publicação em livro censurada: Maria da Ponte, de Guilherme Figueiredo; Rasga coração, de Oduvaldo Vianna Filho; Canteiro de obras e O belo burguês, de Pedro Porfírio; Quarto de empregada, de Roberto Freire; e as peças Abajur lilás e Barrela, de Plínio Marcos. Note-se que, aqui, estamos destacando apenas a publicação em livros de peças teatrais, diferente de sua encenação.

Quanto à encenação, o mecanismo de funcionamento da censura era de outra ordem. Apenas em 1965 foram proibidas as encenações de $O$ berço do herói, de Dias Gomes; Brasil pede passagem, espetáculo com textos de Castro Alves e Sérgio Porto; Berço esplêndido, de Sérgio Porto; e mais três peças estrangeiras, de Gorki, Brecht e Feideau, depois liberadas (cf. Visão, 11.3.1974, p.143).

A peça O berço do herói, de Dias Gomes, escrita em 1963, teve uma trajetória complexa. Sua encenação foi proibida pela censura federal em 1965, ao mesmo tempo que a publicação em livro alcançou sucesso de vendas. Dez anos depois, em 1975, Dias Gomes adaptou o enredo básico de O berço do herói para telenovela sob o título Roque Santeiro. Naquele ano, já com 36 capítulos gravados, Roque Santeiro teve sua transmissão censurada no dia da estreia. No programa Globo Repórter 40 anos de telenovela, transmitido pela Rede Globo em 1991, Dias Gomes relata que havia contado para Nelson Werneck Sodré, por telefone, que Roque Santeiro era uma adaptação de O berço do herói e que apenas depois soube que o telefone de Nelson Werneck Sodré estava "grampeado". Em 1985, a mesma telenovela voltou a ser produzida e obteve enorme sucesso de audiência. 
Em casos como esse, em que há uma interdição para exibições públicas mas o livro está publicado, ocorre um fenômeno curioso: algo "que não pode ser visto por plateias adultas pagando ingressos, está ao alcance de qualquer pessoa que saiba ler" (Castro, 2000, p.197). Casos similares ocorreram com os filmes Macunaima (Joaquim Pedro, 1969), São Bernardo (Leon Hirszman, 1972) e Toda nudez será castigada. (Arnaldo Jabor, 1972), que receberam cortes ou ficaram retidos pela censura (Simões, 1998, p.32, 155, 181).

Outro caso de ações censoras diversas para meios de comunicação diferentes ocorreu em 1973 em relação à peça Calabar, de Chico Buarque de Holanda e Ruy Guerra. O texto foi liberado pela censura prévia para publicação em livro, porém a encenação foi censurada e o disco teve que alterar a capa prevista. Chico Buarque, no DVD Bastidores (RWR Comunicações, 2005) relembra assim o episódio:

[...] os jornais eram proibidos de noticiar a proibição e as pessoas chegavam na bilheteria e não entendiam [...] e já tinha os cartazes preparados "leia o livro, assista a peça, compre o disco Calabar". [...] O livro foi liberado $[\ldots]$ o espetáculo simplesmente deixou de existir $[\ldots]$ e o disco $[\ldots]$ saiu com uma capa branca $[\ldots]$ e ficou sendo Chico Canta.

\section{Livros não ficcionais}

No acervo de documentos do antigo Departamento de Censura de Diversões Públicas encontram-se os processos que geraram os vetos de dois livros de não ficção de autores brasileiros: Programa de Saúde de Lídia Rosenberg Aratangy e outros, publicado pela Companhia Editora Nacional, vetado em 1978; e Basta bastardos, de Helio de Almeida, vetado em 1970.

O livro Programa de Saúde: projetos e temas de higiene e saúde, de Lídia Rosenberg Aratangy, Silvio de Almeida Toledo Filho e Oswaldo Frota-Pessoa, é uma obra didática voltada para o então ensino de segundo grau, equivalente ao atual ensino médio. Em suas primeiras páginas está explicitado que a finalidade do livro é fazer os alunos "mergulharem na realidade sanitária de suas comunidades" e assim adquirirem "conhecimentos genuínos e a adoção de comportamentos desejáveis nessa área". O livro foi vetado com a argumentação de que poderia haver, por parte dos professores sem treinamento específico, má utilização das informações contidas e propiciadas pelo livro e isso poderia "causar sérios problemas no espírito da juventude brasileira" (Reimão, 2013).

O caso de Basta bastardos é muito diferente e específico: os originais foram encaminhados para o DCDP pelo próprio autor e o parecer que subsidiou o veto salienta que o texto apresenta "perigoso caráter de antissemitismo, absolutamente insustentável ante as leis do País".

Utilizando como fonte de informação os pareceres do DCDP e produções bibliográficas várias, destacadamente os livros Nos bastidores de censura, de Dionísio da Silva (1989), e A ditadura escancarada, de Elio Gaspari (2002b), 
pode-se estabelecer que, pelo menos, dezoito livros não ficcionais de autores brasileiros foram vetados durante a ditadura militar brasileira. São eles:

- O mundo do socialismo, de Caio Prado Jr. (São Paulo, Brasiliense, 1962).

História militar do Brasil, de Nelson Werneck Sodré (Rio de Janeiro, Civilização Brasileira, 1965).

- A revolução brasileira, de Caio Prado Jr. (São Paulo, Brasiliense, 1966).

- A mulher na construção do mundo futuro, de Rose Marie Muraro (Petrópolis, Vozes, 1966).

- Torturas e torturados, de Márcio Moreira Alves (Rio de Janeiro, Idade Nova, 1967).

- A automação e o futuro do homem, de Rose Marie Muraro (Petrópolis, Vozes, 1968).

- A Universidade necessária, de Darcy Ribeiro (Rio de Janeiro, Paz e Terra, 1969).

- O poder jovem: história da participação politica dos estudantes brasileiros, de Arthur José Poerner (Rio de Janeiro, Civilização Brasileira, 1968).

- 113 dias de angústia - Impedimento e morte de um presidente, de Carlos Chagas (Rio de Janeiro, Image, 1970).

- O despertar da revolução brasileira, de Márcio Moreira Alves (Lisboa, Seara Nova, 1974).

- América Latina: ensaios de interpretação econômica, de José Serra (Coord.) e Celso Furtado, Maria da Conceição Tavares, Fernando Henrique Cardoso, Anibal Pinto, Pedro Vuskovic Bravo, Fernando Fajnzylber, Paulo R. Souza, Victor E. Tokman, Arturo O'Connell, Charles Rollins, Mario la Fuente (Rio de Janeiro, Paz e Terra, 1976).

- Programa de Saúde: projetos e temas de higiene e saúde, de Lídia Rosenberg Aratangy, Silvio de Almeida Toledo Filho, Oswaldo Frota-Pessoa (São Paulo, Companhia Editora Nacional, 1976).

- Contradições urbanas e movimentos sociais, de J. Álvaro Moises, Verena Martinez-Alier, Francisco de Oliveira, Sergio de Souza (Rio de Janeiro, Paz e Terra, Cedec, 1977).

- Classes médias e politica no Brasil, de J. A. Guilhon Albuquerque (Coord.), Alain Touraine, Braz J. Araújo, Fernando Henrique Cardoso, Gilberto Velho, M. A. Salvo Coimbra (Rio de Janeiro, Paz e Terra, 1977).

- Movimento estudantil e consciência social na América Latina, de J. A. Guilhon Albuquerque (Rio de Janeiro, Paz e Terra, 1977).

- Memórias: a verdade de um revolucionário, de Olympio Mourão Filho (Porto Alegre, L\&PM, 1978).

- Dicionário do palavrão e termos afins, de Mário Souto Maior (Recife, Guararapes, s. d.).

- Basta bastardos, de Helio de Almeida (1970 - ver início deste item). 


\section{Livros eróticos/pornográficos}

Nos arquivos do DCDP encontram-se indicações de 70 livros eróticos/ pornográficos de autores brasileiros vetados; o livro de Deonísio da Silva (1989), Nos bastidores da censura, apresenta 69 títulos com esse perfil; comparando-se as duas listagens e excluindo-se as repetições, resulta que cerca de 100 livros eróti$\cos$ /pornográficos de autor nacional foram censurados no período da ditadura militar.

Entre esses, 18 são de autoria de Cassandra Rios; 13, de Adelaide Carraro; 22 são assinados como Dr. G. Pop; 17, como Brigitte Bijou; e seis, como Márcia Fagundes Varella.

Adelaide Carraro e Cassandra Rios foram, nos anos 1960 e 1970, campeãs de vendagem. Seus livros, considerados eróticos ou francamente pornográficos, eram lidos às escondidas por adolescentes e adultos. Eram livros "fortes" que misturavam política, "negociatas" e sexo, muito sexo. E como tais eram lidos.

Os livros de Adelaide Carraro proibidos pela censura foram: Carniça; $O$ castrado; O Comitế; De prostituta a primeira dama; Escuridão; Falência das elites; Os padres também amam; Podridão; Sexo em troca de fama; Submundo da sociedade; A verdadeira história de um assassino; Mulher livre e Os amantes.

Os livros de Cassandra Rios censurados foram: A borboleta branca; Breve história de Fábia; Copacabana Posto Seis; Georgette; Maçaria; Marcella; Uma mulher diferente; Nicoleta Ninfeta; A sarjeta; As serpentes e a flor; Tara; Tessa, a gata; As traças; Veneno; Volúpia do pecado; A paranoia; O prazer de pecar e Tentação sexual.

Os livros de G. Pop, Brigitte Bijou e Márcia Fagundes Varella censurados ostentavam títulos como: Astúcia sexual; Cidinha a insaciável; Graziela amava e ...matava; Clube dos prazeres; O padre fogoso de Boulange ou Noviça erótica.

Não nos esqueçamos de que parte dos militares via a sexualidade podendo ser utilizada como ferramenta do "expansionismo comunista". Exemplos dessa postura foram coletados por Paolo Marconi (1980) em A censura política na imprensa brasileira; citemos um, nas palavras do tenente-coronel Carlos de Oliveira:

O sexo é um instrumento usado pelos psicopolíticos para perverter e alienar a personalidade dos indivíduos [...] Daí partem para o descrédito das famílias, dos governos, e passam à degradação da nação, bem como intensificam a divulgação da literatura erótica e da promiscuidade sexual. (Marconi, 1980, p.18)

\section{Romances, contos e poesias}

Além dos textos teatrais já abordados aqui, outras obras de ficção de autores nacionais foram censuradas durante os anos de vigência do AI-5. Segundo a listagem do acervo do DCDP e o citado levantamento de Deonísio da Silva, foram elas: Quatro contos de pavor e alguns poemas desesperados, Álvaro Alves de 
Faria; Dez histórias imorais, de Aguinaldo Silva; Meu companheiro querido, de Alex Polari; Zero - romance pré-histórico, de Ignácio de Loyola Brandão; Em câmara lenta, de Renato Tapajós; Aracelli, meu amor, de José Louzeiro; Feliz Ano Novo, de Rubem Fonseca; Diário de André, de Brasigóes Felício; e os contos "Mister Curitiba" de Dalton Trevisan e "O cobrador" de Rubem Fonseca.

O livro Quatro cantos de pavor e alguns poemas desesperados, de Álvaro Alves de Faria, percorreu um trajeto editorial bastante curioso: em 1973 o autor encaminhou, por iniciativa própria, os originais do livro para o DCDP. O texto recebeu um parecer indicativo de veto. Independentemente desse processo, e sem conhecimento do parecer, o livro foi editado, em 1973, pela editora Alfa-Ômega.

O veto à obra de José Louzeiro, Aracelli, men amor, pelo Ministério da Justiça, é um caso muito específico. O livro relata um caso real: o estupro e o assassinato da menina de nove anos Aracelli Cabrera Crespo por três jovens de famílias da elite de Vitória, Espírito Santo. Apesar de se tratar de um relato ficcional, o texto utiliza os nomes dos acusados. As famílias dos acusados manifestaram-se judicialmente contra o fato e o Ministério da Justiça suspendeu a publicação e a circulação do livro por algum tempo enquanto o processo transcorria, mas, ainda assim, houve nova edição mesmo antes do fim do processo (Hallewell, 2005, p.593).

Os contos "Mister Curitiba" de Dalton Trevisan e "O cobrador" de Rubem Fonseca foram vetados previamente pelo DCDP quando venceram concursos de contos da revista Status em 1976 e 1978, respectivamente. A revista Status, assim como as revistas Inéditos (revista mineira de cultura e literatura), Paralelo (de Porto Alegre), Homem (hoje Playboy), Ele e Ela, Nova e Pais e Filhos estavam entre aquelas que, a cada edição, deveriam remeter os originais previamente ao DCDP (Marconi, 1980, p.61).

Alex Polari consta na listagem de Deonísio da Silva como tendo seu poema "Meu companheiro querido" censurado. Nas listagens de livros examinados pelo DCDP não localizamos referências a Polari. Alex Polari foi preso em maio de 1971 e quando saiu seu primeiro livro, Inventário de cicatrizes, ele ainda estava preso. Não conseguimos localizar o poema a que Deonísio da Silva se refere e nem as circunstâncias do veto. Em 1979, em virtude da Lei da Anistia, Alex Polari foi solto e publicou seu segundo livro, Camarim de prisioneiro.

Os livros Dez histórias imorais, de Aguinaldo Silva (Record, 2.ed., 1969); Diário de André, de Brasigóes Felício (Oriente, 1974, vetado em 1976); Zeroromance pré-histórico, de Ignácio de Loyola Brandão (Ed. Rio/Brasília, 1976); Feliz Ano Novo, de Rubem Fonseca (Artenova, 1976) e Em câmara lenta, de Renato Tapajós (Alfa-Ômega, 1977) foram publicados, distribuídos, comercializados e algum tempo depois, meses ou anos, foram examinados pelo DCDP cujo parecer (na maioria dos casos) tornou-se base do decreto de proibição e apreensão assinado pelo ministro da Justiça com a formulação: "proíbo a pu- 
blicação e circulação em todo o território nacional [...] bem como determino a apreensão de todos os seus exemplares expostos à venda, por exteriorizarem matéria contrária à moral e aos bons costumes".

No arquivo dos documentos do DCDP encontram-se os processos e os pareceres de Quatro cantos de pavor e alguns poemas desesperados, Dez histórias imorais, Diário de André e Feliz Ano Novo.

Apesar de nas obras ficcionais, listadas antes, censuradas pela ditadura militar a temática sexual ser bastante presente, elas não são obras que possam ser classificadas como eróticas ou pornográficas.

O traço que parece ser mais evidente entre essas obras literárias é a filiação a uma certa literatura da violência - violência física e psicológica das prisões e torturas, a impunidade dos criminosos como mecanismo propulsor da violência, violência ensandecida e sem rumo dos marginalizados e excluídos - violências essas que a ditadura militar propiciara ou era incapaz de conter e se esforçava por ocultar.

\section{Sobre o conjunto dos pareceres do DCDP}

Os dados quantitativos gerais sobre censura a livros calculados a partir dos documentos disponíveis no acervo preservado do DCDP listados anteriormente indicam que a atividade censória, nesse setor, foi mais rígida entre 1975 e 1980, período em que mais de $50 \%$ dos livros submetidos foram vetados, enquanto entre 1970 e 1973 esse percentual ficava muito abaixo desse número.

A censura a livros durante a ditadura militar, portanto, teve uma atuação mais forte não nos chamados Anos de Chumbo (1968-1972), mas sim durante o governo Geisel (março de 1974 a março de 1979), e especialmente no final desse governo. Sendo o governo Geisel, apesar dos momentos de retrocessos, aquele em que se iniciou o processo de abertura política lenta e gradual. A censura a livros por parte do DCDP foi maior quando a maioria dos jornais e revistas estava sendo liberada da presença da censura prévia nas redações.

Pode-se dizer que a censura a livros durante a ditadura militar apresenta uma dinâmica similar a outros setores das diversões públicas: dados do DCDP indicam que também o teatro e o cinema foram mais vetados durante o governo Geisel (Fico, 2002, nota 170).

Três hipóteses podem explicar a diferença da repressão censória relativa e jornais e revistas e aquela relativa às diversões públicas.

A primeira hipótese seria a de que o DCDP teria, grosso modo, um escopo censório mais moral e menos político, e essa censura moral, nas palavras de Carlos Fico (2002, p.22), "obedecia a outros ditames, embora não tenha ficado imune às peculiaridades do regime militar. Ela dizia respeito a antigas e renovadas preocupações de ordem moral, muito especialmente vinculadas às classes médias urbanas". 


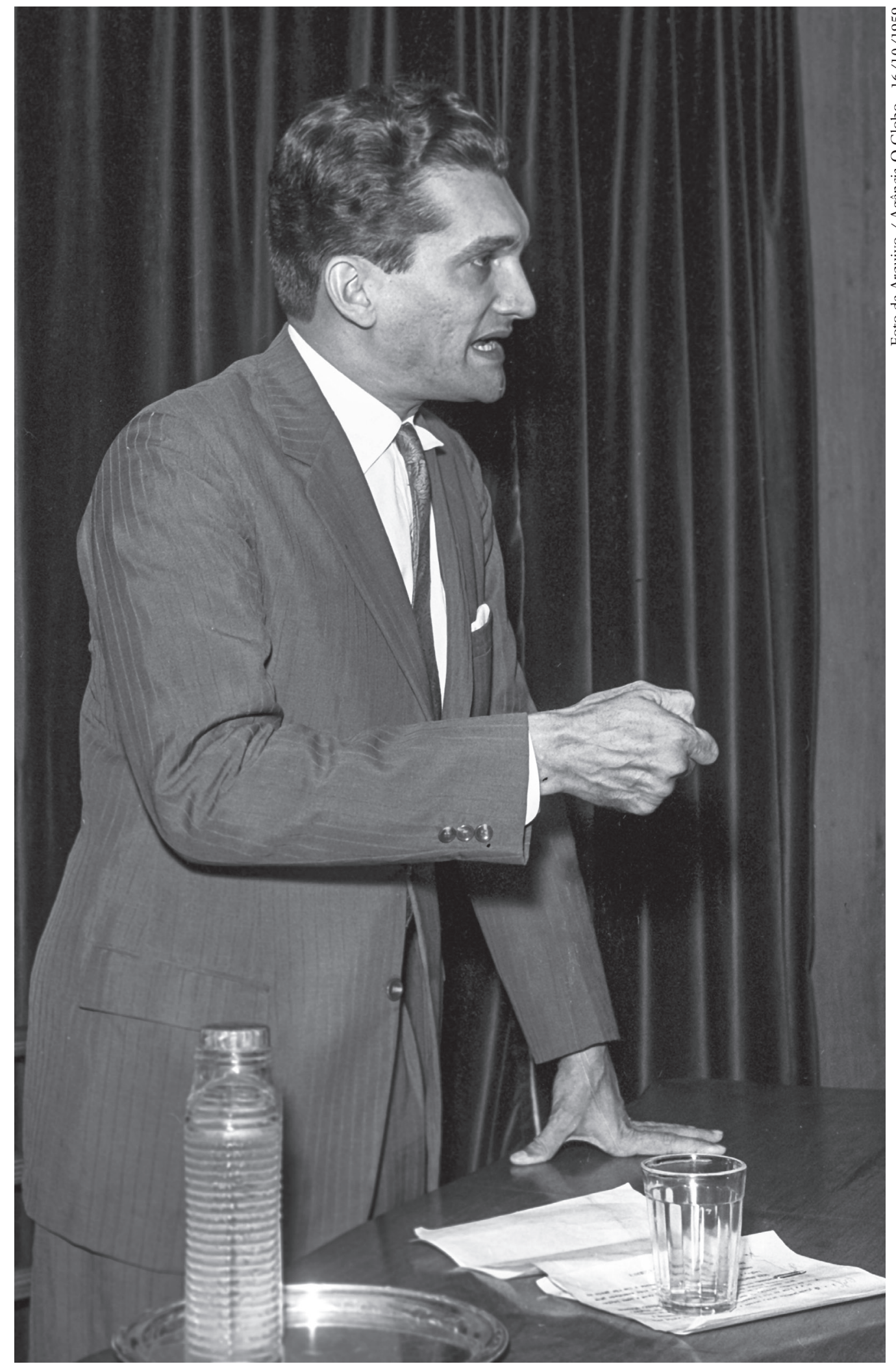

Celso Furtado foi autor de ensaio editado em obra da Paz e Terra vetada durante a ditadura. 


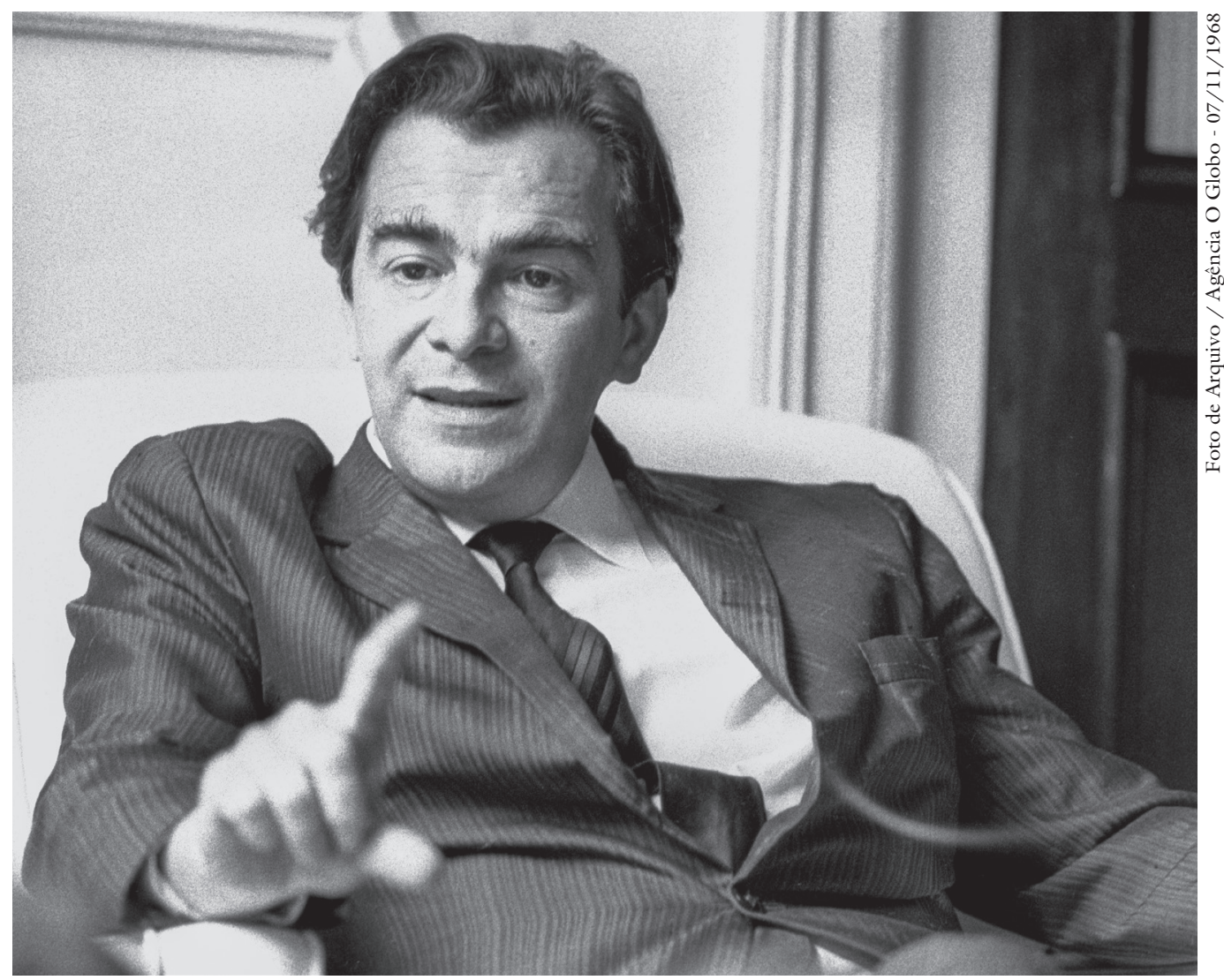

Darcy Ribeiro, autor da obra A Universidade necessária (1969) vetada pelo regime.

A segunda hipótese para se entender a grande atividade censória do DCDP em relação a livros, teatro, cinema e televisão após a posse de Geisel, e especialmente nos dois últimos anos de seu governo, é a de que o próprio DCDP, percebendo a possibilidade do fim das atividades censórias, buscou mostrar-se como necessário ao sistema.

Essa segunda hipótese pode ser reforçada pelo fato, citado por Gaspari (2004, p.488), de que em junho de 1974 a Censura proibiu que se publicasse "a declaração de um deputado contando que Golbery lhe disse, durante uma audiência, que se vai acabar com a censura".

Uma terceira hipótese, de certa forma correlacionada à segunda, seria a de que durante os anos de chumbo (1968-1972) artistas e intelectuais exerciam a autocensura pois estavam conscientes do rigor da atividade censória que, durante o governo Médici (1969-1974), "ficou prioritariamente em mãos dos militares da 'linha dura"' (Aquino, 2002, p.530), evitando produzir obras que pudessem ser censuradas. Como observou Bernardo Kucinski (2002, p.536), a existência de uma censura rigorosa "induz ao exercício generalizado da autocensura”. A autocensura explicaria o índice proporcionalmente menor - em relação ao total dos examinados - de livros, peças de teatro e filmes censurados durante os anos de chumbo. 


\section{Observações finais}

Durante a ditadura militar brasileira, a edição de livros foi, inicialmente, vítima de atos de vandalismos da direita e, a partir de 1970, coagida por uma legislação de censura prévia. O estudo que empreendemos sobre a censura a livros na ditadura militar nos permitiu identificar livros de autores nacionais vetados no período e delinear alguns procedimentos censórios. De maneira geral, como observações finais, podemos dizer que nosso trajeto nos conduz a três constatações.

A primeira é a do limite de qualquer ato de coação censória: toda coação é temporária e limitada - "pode-se reprimir o espírito por um curto espaço de tempo, mas, no final, o espírito sempre vence" -, frase dita pelo bibliófilo José Mindlin em entrevista a nós concedida em novembro de 2008.

A segunda observação geral a que o estudo realizado nos conduz é a de que o estabelecimento de um esquema censório é uma violência à cidadania. Concebemos a censura como parte de um aparelho de coerção e repressão que, muito mais do que afetar a circulação de alguns bens culturais, restringia a produção e circulação da cultura, implicando uma profunda mudança no exercício da cidadania e da cultura.

O estudo conduziu-nos, por fim, à verificação da existência de grande número de ações de resistência à opressão. Foram muitos os atos e as manifestações contra a censura por parte de grandes escritores, como Jorge Amado e Erico Verissimo, e também por parte de grandes intelectuais e editores, como Ênio Silveira; e, por fim, e talvez principalmente, foram muitos os atos de resistência protagonizados por uma legião de anônimos - pequenos e médios editores, impressores e livreiros que, no limite de seus campos de ação, atuaram com dignidade e em prol da liberdade, mesmo em tempos sombrios. Não nos esqueçamos de incluir os leitores nessa silenciosa legião de pessoas que, com pequenos atos, buscaram preservar os direitos humanos essenciais nas adversidades - pois, lembremos, em certos momentos, até mesmo comprar, carregar e guardar alguns livros podia ser perigoso.

\section{Referências}

AQUINO, M. A. Mortos sem sepultura. In: CARNEIRO, M. L. T. (Org.) Minorias silenciadas. História da censura no Brasil. São Paulo: Edusp; Imprensa Oficial; Fapesp, 2002.

CASTRO, R. O anjo pornográfico. A vida de Nelson Rodrigues. São Paulo: Cia. das Letras, 2000.

CCSP. Cronologia das Artes em São Panlo 1975-1995. São Paulo: Centro Cultural São Paulo, 1996. 5v.

COSTELA, A. O controle da imprensa no Brasil. Petrópolis: Vozes, 1970. 
JONES, D. (Ed.) Censorship. A World Encyclopedia. London; Chicago: Fitzroy Dearborn Publishers, 2001. 4v.

FICO, C. "Prezada Censura": Cartas ao Regime Militar. Topoi - Revista de História, Rio de Janeiro, n.5, p.251-86, set. 2002.

GASPARI, E. A ditadura envergonhada. São Paulo: Cia. das Letras, 2002a. A ditadura escancarada. São Paulo: Cia. das Letras, 2002 b. A ditadura encurralada. São Paulo: Cia. das Letras, 2004.

HALLEWELL, L. O livro no Brasil. 2.ed. São Paulo: Edusp, 2005.

KUCINSKI, B. A primeira vítima: a autocensura durante o regime militar. In: CARNEIRO, M. L. T. (Org.) Minorias silenciadas: história da censura no Brasil. São Paulo: Edusp; Imprensa Oficial; Fapesp, 2002.

MARCONI, P. A censura politica na imprensa brasileira (1968-1978). São Paulo: Global, 1980 .

REIMAO, S. Mercado editorial brasileiro. São Paulo: Com-Arte; Fapesp, 1996.

O livro Programa de saúde: um caso de censura durante a ditadura militar brasileira. História, Ciências, Saúde - Manguinhos, Rio de Janeiro, v.20, supl., p.1393401, nov. 2013.

SILVA, D. da. Nos bastidores da censura. Sexualidade, literatura e repressão pós-64. São Paulo: Estação Liberdade, 1989.

SIMÕES, I. Roteiro da intolerância. São Paulo: Ed. Senac; Terceiro Nome, 1998.

STEPHANOU, A. A. A perda da inocência. Visão, São Paulo, 11 mar. 1974. (Edição especial: “Assim se passaram 10 anos”).

Feliz ano novo? Veja. São Paulo, 29 dez. 1976, p.81-2.

2001 .

Censura no regime militar e militarização das artes. Porto Alegre: Edipucrs,

VENTURA, Zuenir. 1968 O ano que não terminou. A aventura de uma geração. 17 ed. Rio de Janeiro: Nova Fronteira, 1988.

RESUMO - Durante a ditadura militar brasileira (1964-1985), cerca de 140 livros de autores brasileiros foram oficialmente vetados pelo Estado. Este artigo apresenta parte dos resultados de um projeto que visou fazer o levantamento sistemático das obras censuradas e traçar um panorama da atuação censória do governo militar em relação a livros, destacadamente obras de autores brasileiros, com ênfase no período posterior a 1970. Além de fontes bibliográficas, utilizamos o arquivo de pareceres do Departamento de Censura de Diversões Públicas (DCDP), órgão do Ministério da Justiça, que a partir de 1970 passou a exercer a censura a livros e revistas. O presente artigo é uma versão modificada de trechos do livro Repressão e resistência: censura a livros na ditadura militar, publicado pela Edusp, com apoio da Fapesp, em 2011.

PALAVRAS-CHAVE: Censura, Livros, Ditadura militar, DCDP. 
ABSTRACT - Under the Brazilian military dictatorship (1964-1985), around 140 books by Brazilian writers were officially vetoed by the State. This article presents some of the results of a project that involved drawing up a systematic list of those works that were censored, so as to form an overview of the military government's approaches to censorship in relation to the books, particularly those by Brazilian writers, and with emphasis on the period after 1970. In addition to using bibliographic sources, we also looked at the archives of rulings by the Department for Public Entertainment Censorship (DCDP), part of the Ministry of Justice, which took over the censorship of books and magazines from 1970. The present article is a modified version of extracts from the book Repressão e resistência: censura a livros na ditadura militar [Repression and resistance: book censorship under the military dictatorship], published in 2011 by Edusp with support from Fapesp.

KEYWORDS: Censorship, Books, Military dictatorship, DCDP.

Sandra Reimão é professora da Universidade de São Paulo, na Escola de Artes, Ciências e Humanidades (EACH) e no Programa de Pós-Graduação em Comunicação da Escola de Comunicações e Artes (PPGCOM-ECA). Pesquisadora de Produtividade em Pesquisa 1D do CNPq. Publicou, entre outros, os livros: Livros e televisão - correlações (Ateliê, 2004) e Repressão e resistência - censura a livros na ditadura militar (Edusp; Fapesp, 2011). @-sandra.reimao@gmail.com

Recebido em 15.1.2014 e aceito em 5.2.2014.

I Escola de Artes, Ciências e Humanidades (EACH), Universidade de São Paulo, São Paulo/SP, Brasil. 